\title{
Developing surface water flood forecasting capabilities in Scotland: an operational pilot for the 2014 Commonwealth Games in Glasgow
}

Article

Accepted Version

Speight, L., Cole, S. J., Moore, R. J., Pierce, C., Wright, B., Golding, B., Cranston, M., Tavendale, A., Dhondia, J. and Ghimire, S. (2018) Developing surface water flood forecasting capabilities in Scotland: an operational pilot for the 2014 Commonwealth Games in Glasgow. Journal of Flood Risk Management, 11 (52). S884-S901. ISSN 1753-318X doi: https://doi.org/10.1111/jfr3.12281 Available at https://centaur.reading.ac.uk/76399/

It is advisable to refer to the publisher's version if you intend to cite from the work. See Guidance on citing.

Published version at: https://onlinelibrary.wiley.com/doi/10.1111/jfr3.12281

To link to this article DOI: http://dx.doi.org/10.1111/jfr3.12281

Publisher: Wiley-Blackwell

All outputs in CentAUR are protected by Intellectual Property Rights law, including copyright law. Copyright and IPR is retained by the creators or other copyright holders. Terms and conditions for use of this material are defined in the End User Agreement. 


\section{www.reading.ac.uk/centaur}

\section{CentAUR}

Central Archive at the University of Reading

Reading's research outputs online 


\title{
Developing surface water flood forecasting capabilities in Scotland: an operational pilot for the 2014 Commonwealth Games in Glasgow
}

\author{
Linda Speight ${ }^{1}$, Steven J. Cole ${ }^{2}$, Robert J. Moore ${ }^{2}$, Clive Pierce ${ }^{3}$, Bruce Wright ${ }^{3}$, Brian \\ Golding $^{3}$, Michael Cranston ${ }^{1}$, Amy Tavendale ${ }^{1}$, Juzer Dhondia ${ }^{4}$, Sohan Ghimire ${ }^{5}$ \\ ${ }^{1}$ Scottish Environment Protection Agency, , Perth, PH1 1RX, UK \\ ${ }^{2}$ Centre for Ecology \& Hydrology, Wallingford, OX10 BBB, UK \\ ${ }^{3}$ Met Office, Exeter, Devon, EX1 3PB, UK \\ ${ }^{4}$ Deltares - Delft Hydraulics, PO Box 177, 2600 MH Delft, Netherlands \\ ${ }^{5}$ The James Hutton Institute, Craigiebuckler, Aberdeen, AB15 8QH, UK
}

\begin{abstract}
Existing surface water flood forecasting methods in Scotland are based on indicative depthduration rainfall thresholds with limited understanding of the likelihood of inundation or associated impacts. Innovative risk-based solutions are urgently needed to advance surface water forecasting capabilities for improved flood resilience in urban centres.

A new model based solution was developed for Glasgow linking 24 hour ensemble rainfall predictions from the Met Office Global and Regional Ensemble Prediction System for the UK (MOGREPS-UK) with static flood risk maps through the Grid-to-Grid hydrological model. This new forecasting capability was used operationally by the Scottish Flood Forecasting Service during the 2014 Commonwealth Games to provide bespoke surface water flooding guidance to responders. The operational trial demonstrated the benefits of being able to provide targeted information on real-time surface water flood risk. It also identified the high staff resource requirement to support the service due to the greater uncertainty in surface water flood forecasting compared to established fluvial and coastal methods.
\end{abstract}

\section{Key words (up to 8)}

Communication, flood forecasting, impacts, probabilistic, surface water, urban

\section{Glossary of flood forecasting acronyms used}

$\begin{array}{ll}\text { DSWFF } & \text { Daily Surface Water Flood Forecast } \\ \text { ERA } & \text { Extreme Rainfall Alert } \\ \text { FEWS } & \text { Delft Flood Early Warning System } \\ \text { FFC } & \text { Flood Forecasting Centre for England and Wales } \\ \text { FGS } & \text { Flood Guidance Statement } \\ \text { G2G } & \text { Grid-to-Grid distributed hydrological model } \\ \text { MACC } & \text { Multi Agency Control Centre } \\ \text { MOGREPS-UK } & \text { Met Office Global and Regional Ensemble Prediction System for UK } \\ \text { NFRA } & \text { National Flood Risk Assessment } \\ \text { NHP } & \text { Natural Hazards Partnership } \\ \text { NSWWS } & \text { Met Office National Severe Weather Warning Service } \\ \text { NWP } & \text { Numerical Weather Prediction } \\ \text { SCC } & \text { SEPA Communication Centre } \\ \text { SCG } & \text { Strategic Co-ordinating Group }\end{array}$




$\begin{array}{ll}\text { SEPA } & \text { Scottish Environment Protection Agency } \\ \text { SFFS } & \text { Scottish Flood Forecasting Service } \\ \text { SGoRR } & \text { Scottish Government Resilience Room } \\ \text { STEPS } & \text { Short Term Ensemble Prediction System } \\ \text { SWFDST } & \text { Surface Water Flooding Decision Support Tool } \\ \text { UKV } & \text { Met Office NWP Variable resolution UK forecasting model }\end{array}$

\section{Introduction}

There is a growing demand for more robust, accurate and timely forecasts for surface water flooding to facilitate effective mitigation actions. In Scotland the National Flood Risk Assessment (NFRA) published in December 2011 estimated that around 125,000 properties are at risk of flooding from rivers, the sea and surface water. Surface water accounts for approximately $38 \%$ of the predicted impacts (SEPA, 2011).

Following widespread flooding in England and Wales in summer 2007, The Pitt Report (Cabinet Office, 2008) identified a requirement to improve forecasting tools for surface water flooding. The Environment Agency and the Met Office first launched a rainfall threshold-based Extreme Rainfall Alert (ERA) service for England and Wales in 2009. This was superseded in 2011 by the Surface Water Flooding Decision Support Tool (SWFDST, Halcrow, 2011) which is used within the Flood Forecasting Centre (FFC) for England and Wales, along with expert hydrometeorological judgement, to provide guidance on surface water flood risk. In addition to rainfall thresholds, the SWFDST takes some account of soil wetness and rainfall duration. In Scotland the Scottish Flood Forecasting Service (SFFS), a partnership between SEPA and the Met Office established in 2011, provides daily guidance on surface water flooding through the Flood Guidance Statement (FGS) available to emergency responders and via regional flood alerts (of which there are 19 in Scotland) for the public. The tools used to inform existing surface water flood forecasting in Scotland are based on indicative depth-duration impact thresholds (Halcrow, 2012) for both deterministic and probabilistic rainfall forecasts.

Feedback from responders and the public (Cabinet Office, 2008; Halcrow, 2011; Ipsos MORI, 2013; Ochoa-Rodriguez et al., 2013) has identified that although current guidance on surface water flooding is perceived as useful, more targeted information would be beneficial. There is also an established economic benefit from improving surface water flood warning, for example to support property level protection schemes (JBA Consulting, 2014a).

Improvements in computational ability (e.g. Glenis et al., 2013; Lamb et al., 2009; Neal et al., 2010) and in convection-permitting numerical weather prediction (NWP) and ensemble forecasts (Golding et al., 2014) mean that it is now potentially possibly to develop innovative approaches to surface water flood forecasting in urban areas. However, due to the rapid onset and localised nature of surface water flooding, the predictability of the probability of occurrence is likely to remain low at lead-times beyond a few hours.

This paper considers recent developments in convection-permittingNWP and real-time surface water modelling in urban areas. A review (Ghimire et al., 2013a) was used to inform the development of a fully risk-based surface water forecasting model for Glasgow that met end-user requirements to provide specific impact information with a 6 to 24 hour lead-time, and that could be integrated with existing SFFS tools. Details are provided of the technical set-up of the model. Two case studies of heavy rainfall events during the 2014 Commonwealth Games serve to illustrate the operational use of the model by the SFFS and 
to highlight the benefits and challenges of providing targeted surface water forecasts at a city scale.

\section{Quantitative Precipitation Forecasting (QPF) for convective events}

The accuracy of real-time surface water flood forecasting is constrained by rainfall forecast accuracy. Beyond six hours ahead, NWP provides the most accurate forecasts of rain-rate. A characteristic of many atmospheric motions, including those that generate convective rainfall, is that the lifetime of a disturbance gets shorter as its size gets smaller, and that the lead-time for which the disturbance can be usefully predicted with a perfect model, is related to its lifetime (Germann and Zawadzki 2002, 2004). Thus, while average properties of a $1000 \mathrm{~km}$ by $1000 \mathrm{~km}$ area of tropical air giving rise to convective rainstorms may ultimately be predictable by an NWP model up to nine days ahead, an individual $10 \mathrm{~km}$ by $10 \mathrm{~km}$ rainstorm is unlikely ever to be deterministically predictable beyond 3 hours ahead, and the most intense $1 \mathrm{~km}$ by $1 \mathrm{~km}$ part of the storm may only ever be deterministically predictable for 30 minutes ahead. On the other hand, given a sufficiently accurate prediction of the larger area, the probability of intense rainfall occurring at particular times and places should be predictable (Golding, 2009). A NWP model is called "convection-permitting" if it directly represents the upward and downward motions within convective clouds, rather than representing their net effect on the atmosphere using a parameterisation. Several studies have shown the benefits of this (Done et al., 2004; Clark et al., 2009). Convective-scale models are used to add detail about convective rainstorms and other small-scale weather phenomena over a small area. The location, timing and character of the predicted rainstorms depend critically on larger scale information imported from a global model through boundary conditions. The United Kingdom Variable resolution (UKV) model with a $1.5 \mathrm{~km}$ grid (Tang et al., 2013) is often very skilful at predicting maximum rainfall accumulations. However, the timing and location are subject to substantial uncertainty (typically one hour and $25 \mathrm{~km}$ respectively).

Convection-permitting NWP models are expensive to run and are currently only able to approximately match the observations of the initial state due to the dependence on largescale initial conditions and perturbations. Therefore, for lead-times of less than six hours, nowcasting is commonly used. Nowcasts combine current observations from radars with an estimate of the speed and direction of movement to forecast the weather a short period ahead. Nowcasts however do not account for the growth and decay of rain areas over the forecast horizon. A widely adopted solution at very short lead-times (less than six hours) is to blend forecasts from the two methods. The Met Office have used blending in very short-range forecasts since the Nimrod system (Golding, 1998) was introduced. The current approach uses the UK Short Term Ensemble Prediction System (STEPS, Bowler et al., 2004; 2006) nowcast to provide useful radar-rainfall extrapolation ensemble forecasts, blended with the deterministic UKV model. During 2012 a trial was conducted of an hourly update cycle of the UKV over a small area of the southern UK using a 4D-Var data assimilation scheme, enhanced to incorporate additional radar and satellite data (Golding et al., 2014). The trial was run through the summer period, which was characterised by a high frequency of intense convective rainstorms. Analysis of the results is still in progress, but the application of 4D-Var showed clear benefits in converging the initial state and the first few hours of forecast towards the observed state. Operational computing resources however are not currently available to run 4D-Var on an hourly cycle for the whole UK.

In most situations, the predictability of individual convective rainstorms is limited to a few hours ahead. Beyond that time, it is necessary to know the range of uncertainty in the location, timing and intensity of the storms. An ensemble of NWP forecasts is typically created by making small changes to the initial state and to the parameters of the model for each of a set of forecast scenarios. The MOGREPS-UK ensemble with a 2.2km grid length (Golding et 
al., 2014) was introduced by the Met Office for the Olympic Games in 2012 and has since been made operational. Research studies using convective-scale ensembles have explored the sensitivity of the results to a variety of aspects of the ensemble system (Leoncini et al., 2013; Clark et al., 2010). At present, MOGREPS-UK uses global-scale initial conditions and perturbations and so is unable to represent uncertainties in the first few hours of the forecast without incorporation of STEPS.

Results from a study of the July 2011 Edinburgh flooding (Leoncini et al., 2012) and preliminary results from summer 2012 (Golding et al., 2014) indicate that, in atmospheric situations suitable for heavy convective rainfall, the twelve hour ensemble forecast is likely to identify quite a wide area of Scotland to be at risk from intense rainfall. The ensemble prediction system is able to identify days when intense rainfall occurs somewhere with a high degree of reliability (typically around 60\%). However, hourly predictions at city or district scale are characterised by much lower forecast probabilities (typically less than $40 \%$ ). It has also been noted that probabilities are much lower for "random" convection than for more uniform rain areas, even when the observed rates are actually higher in the former case.

\section{Real time flood inundation modelling in urban areas}

Flood risk modelling in urban areas has developed rapidly over recent years. Urban areas are vulnerable to major flood damages due to the density of population and economic and social assets. Urban flooding is becoming more frequent as a consequence of several factors including continued catchment development increasing impervious surfaces, population growth and climate change (Schubert and Sanders, 2012). In recent years, demand for prediction of flooding and flood risk assessment in urban environments has therefore increased markedly (Tingsanchali,2012; Schubert and Sanders, 2012; van Herk et al., 2011; Fernandez and Lutz, 2010; Chen et al., 2009). Advances in remote sensing and computing power have enabled urban flood modelling using high quality terrain data to simulate detailed flow dynamics in local areas (Chen et al., 2012; Schumann et al., 2011).

Published examples of real-time forecasting of surface water flooding in urban areas are limited (Rene et al., 2014). Those that do exist primarily focus on short-term forecasts employing data from local raingauges or weather radar rather than forecast NWP products and have limited surface and subsurface connectivity (Schellart et al., 2011; Henonin et al., 2013; Simoes et al., 2011). The difficulty in delivering surface water forecasting is attributed to both uncertainties in forecasting the type of convective rainstorms that causes surface water flooding and the difficulty in running urban flood inundation models in real-time which limits model complexity.

A further consideration for real-time application is the need for continuous running of a model, involving maintaining model states (e.g. antecedent conditions of water volumes) across all time-steps up to the time the forecast is made. Not all inundation models originally implemented for design and planning are well suited in this respect for real-time application, and may require considerable development and restructuring of the code (Moore et al., 1997). Also, their inputs may relate to an "effective rainfall" design storm profile and may not include an explicit space-time representation of runoff production and water loss accounting. As a result, areas of inundation are not necessarily drained and fully evacuated in the aftermath of a surface water flooding episode, remaining inundated indefinitely.

Modelling in urban areas also embodies additional uncertainties due to the challenge of representing a non-stationary urban environment. For example ongoing land use change and 
re-development as well as ephemeral channel blockages due to urban debris, which are not considered in this paper.

\section{Assessment of impacts}

Flood forecasting in the UK is increasingly risk-based (Dale et al., 2012). The overall risk level is assigned based on expected severity and likelihood of impacts (Figure 1). Therefore an assessment of inundation area alone is not sufficient and further information on expected impacts is required. The definition of impact and likelihood for each cell in the grid matrix is broadly consistent in the UK across the SFFS, FFC and Met Office National Severe Weather Warning Service (NSWWS) (as detailed in SFFS, 2015).

Flood Risk Matrix

(river, tidal/coastal \& surface water flooding)

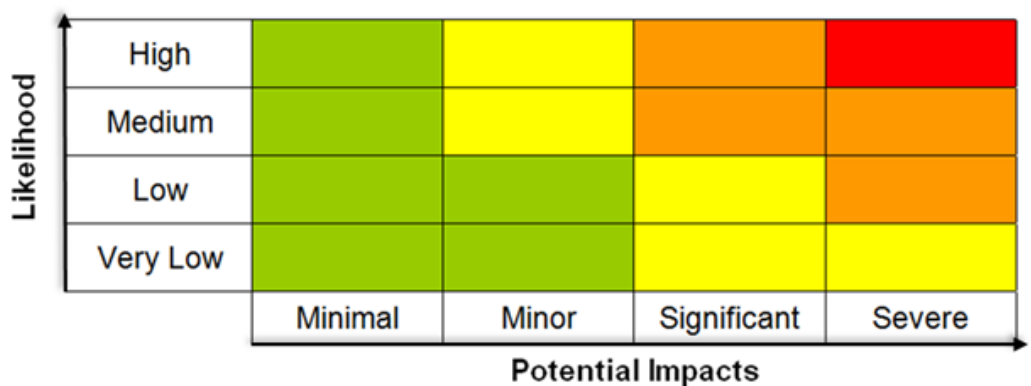

Overall Flood Risk

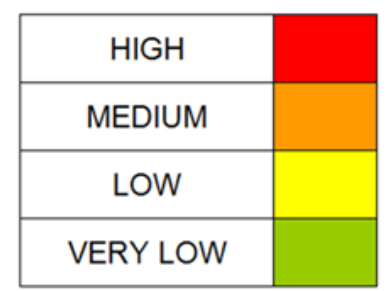

Figure 1 Flood Risk Matrix used by the SFFS for the FGS

The EU Floods Directive 2007/60/EC on the assessment and management of flood risks required all European Member states to produce both flood hazard and flood risk maps including impacts. This is a step change from previous assessments which had mainly focused on flood hazard (de Mole et al., 2009). In Scotland, a strategic assessment of flood impacts from fluvial, coastal and surface water flooding (SEPA, 2013) was made as part of the Flood Risk Management (Scotland) Act 2009, which transposed the EU Directive,. The relevant receptors included in the assessment are: Number of people, Type of economic activity, Businesses and Transport (roads, railways and airports).

Recently there has been a focus on explicitly coupling impact assessments with flood forecasts (Cole et al., 2013). A major modelling issue in relation to surface water flooding is gaining information on impacts and flood extent in order to validate the efficacy of a given modelling approach. A variety of stakeholders collect evidence of surface water flooding in a variety of forms but collation and use of these data for model validation is not straightforward. The use of social media sources is increasingly being considered as a means of collecting evidence of flooding and its impact (Smith et al., 2015).

\section{Developing a surface water forecasting model for Glasgow}

Glasgow has a known history of summer surface water flooding. The most notable, and significant, event occurred in 2002 (MWH, 2002) with subsequent smaller events experienced in 2007, 2011, 2012 and 2013. With the 2014 Commonwealth Games being held in the city, the SFFS judged that if heavy rain was to occur, the existing surface water forecasting capabilities would not be sufficient to meet the expected increased briefing requirements. A project was set up to develop a surface water forecasting model for a $10 \mathrm{~km}$ by $10 \mathrm{~km}$ area of Glasgow to be used in an operational pilot by the SFFS during the Commonwealth Games. 
The experience of setting up and running this pilot service will be used to explore potential future surface water flood forecasting methods for Scotland. The reporting area covered by the operational model is shown in Figure 2.

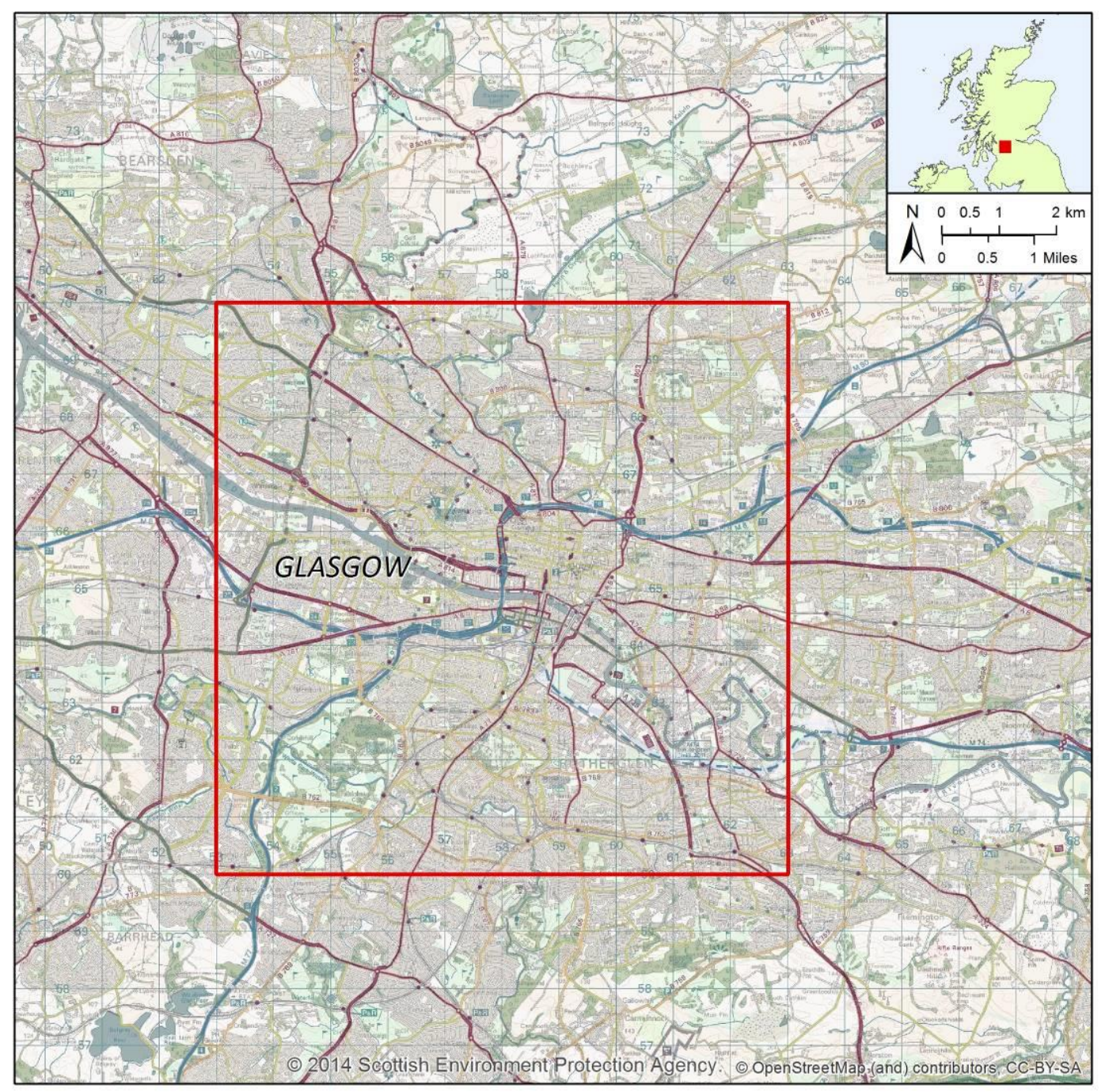

Figure 2 Reporting area of the operational surface water forecasting model for Glasgow

\section{Requirements}

To help ensure the pilot service would meet the priority needs of end-users in relation to the Commonwealth Games, SEPA established a Steering Group of key responders in Glasgow including the City Council, Transport Scotland, Scottish Water and those involved in the Commonwealth Games organisation. This Steering Group provided an excellent forum for project scientists and operational responders to discuss the challenges of surface water flood forecasting from different perspectives, to engage end-users with the project at an early stage, and to set realistic expectations for the operational output.

The Steering Group requirements were to focus on the 6 to 24 hour lead-time to enable proactive preparations. Twelve hours was seen as a critical forecast horizon. Responders wanted guidance on event timings, locations that might be affected, possible impacts and 
severity and, crucially, a stand-down message when the event is over or the risk level reduced. The challenge was to balance the end-user requirements with the scientific capabilities, operational scheduling (e.g. Met Office NWP scheduled run times), and to provide sufficient time for forecaster interpretation and production of a guidance product.

Based on the reviews of NWP for convective events and of real-time flood risk modelling for urban areas, the technical requirements for the operational forecasting model were to:

- Make best use of recent advances in convective NWP by using the Met Office blended short-range ensemble (including MOGREPS-UK and STEPS) and blended nowcast ensembles

- Be capable of regular model initialisation, preferably by continuous running with data assimilation

- Include an explicit assessment of impacts

- Integrate with existing SFFS tools and models

- Be computationally efficient to enable processing in real-time

- Provide surface water flood risk forecasts with a 24 hour lead-time

- Support timely and informed decision-making

\section{Methodology}

The first stage in developing the operational model was to identify a suitable hydraulic and hydrological modelling approach. Ghimire et al. (2013b) details the initial review made of available models and recent urban flood modelling applications based on the CIWEM (2009) guidelines for integrated urban drainage modelling with additional consideration of the potential for use in real-time flood forecasting. Even with recent advances, it was concluded that detailed 2-D hydraulic modelling of surface water flooding remained infeasible to meet the needs of the project and that the sustained investment required to support a robust and verified operational system would be considerable.

Only ISIS FAST (CH2MHILL, 2014) and Grid-to-Grid (G2G, Moore et al., 2006, 2007; Bell et al., 2009) were assessed to have the potential at the present time to be computationally fast enough to run in real-time. G2G has the additional advantage that national versions are used for flood forecasting across the UK (Cranston et al., 2012; Maxey et al., 2012; Price et al., 2012) meaning that operational familiarity with the modelling methodology already exists as well as the technical framework required to run the model. In the G2G model, surface runoff generated within each grid-cell is routed from cell-to-cell to represent flow through the river network and obtain fluvial flood forecasts. Surface runoff is also available to be configured as a G2G output to support forecasting of surface water flooding. The current limitations are its $1 \mathrm{~km}^{2}$ resolution-scale of application and limited verification for surface water flooding; work is ongoing to address the latter whilst finer-scale configuration has been trialled for some G2G applications. Existing approaches for real-time surface water flooding alerts are based on rainfall threshold-exceedance methods. By bringing in dependence on surface cover, soil properties and antecedent wetness condition, G2G offers a potential advance on such approaches. Under the Natural Hazard Partnership (NHP, 2013), a case study has pointed to the potential value of G2G for surface water flooding alerts and further development is ongoing (Cole et al., 2013, 2015). Therefore G2G was selected for use in this application.

The G2G Glasgow model was run on a $1 \mathrm{~km}$ grid over a $22 \mathrm{~km}$ by $22 \mathrm{~km}$ domain of southwest Scotland to reduce the effect of boundary effects on the reporting area (Figure 2). The model was run within the real-time forecasting platform Delft-FEWS (Flood Early Warning System, Werner et al., 2013) and referred to as FEWS Glasgow. Initial model states were imported 
from the national G2G Scotland model run in FEWS Scotland with observed rainfall as input. Rainfall forecasts from the Met Office Best Data short-range ensemble (based on MOGREPS-UK and STEPS) at a $2 \mathrm{~km}$ resolution were separately used as input to the FEWS Glasgow four times a day. The coupling frequency was 15 minutes and 27 hours of forecast rainfall were used (of a possible 32). A length of 27 hours was chosen to mitigate effects of increasing uncertainty in forecasting convective events with increasing lead-time while maintaining 24 hours of useable forecast after the delivery and processing of the forecast. Most of this three hour delay was attributable to processing and data transfer from the Met Office supercomputer to SEPA; because of the small Glasgow model domain the FEWS Glasgow processing time at SEPA was approximately 2.5 minutes. Although the main focus was on the six to 24 hour lead-time, the nowcast ensemble was also used as forecast input to FEWS Glasgow four times a day between the short-range ensemble runs. This enabled the SFFS to review model performance and provide updated forecasts during the working day.

G2G does not provide inundation or impact modelling. This component was provided using a library of existing static inundation and impact assessments from SEPA's Regional Pluvial Flood Hazard maps. The maps were produced as part of the national surface water flood mapping required under the Flood Risk Management (Scotland) Act 2009. Five different rainfall return periods $(10,30,50,100$ and 200 years) for two different storm durations (one and three hours), as well as two climate change scenarios for the 30 and 200 year event were available. The maps were produced using the inundation model JFlow+ (Lamb et al., 2009) supported by a DTM constructed from LiDAR/NEXTMap data with ground levels raised by $0.3 \mathrm{~m}$ to represent buildings. Gridded rainfall depth inputs to the JFlow+ model were based on the Depth-Duration-Frequency rainfall model within the Flood Estimation Handbook (FEH) provided by the Centre for Ecology \& Hydrology $(\mathrm{CEH})$. These were converted to rainfall hyetographs based on the summer rainfall profile described in the FEH to represent the convective storms with short periods of high intensity rainfall that urban catchments are more sensitive to. Rainfall losses were applied to the gross hyetographs to account for differences in drainage and runoff for rural and urban areas. For urban areas the percentage runoff was set to $70 \%$ and losses to the drainage system were assumed to be equivalent to the average 5 -year rainfall for the catchment. Areas with flood depths of less than $0.1 \mathrm{~m}$ were removed due to the relatively low risk these depths pose and the associated uncertainty of the modelling approach (JBA Consulting, 2014b).

Surface runoff for each $1 \mathrm{~km}$ grid cell was simulated by the G2G Glasgow model. Similar to Cole et al. (2012) it was assumed that the surface runoff from the G2G model was equivalent to the effective rainfall used to produce SEPA's regional pluvial flood maps. This meant that for each $1 \mathrm{~km}$ grid square the most appropriate flood inundation map and impact assessment from the offline library could be identified. The three hour surface runoff accumulations were linked to the three hour storm duration impact assessments. A conceptual challenge of this approach was how to convert impact to specific receptors in individual grid cells to an overall assessment of risk. Table 1 shows the SFFS guidance on impacts used in the national Flood Risk Matrix (Figure 1) and the grid-cell impact thresholds used in this application. The grid-cell impact thresholds are specific to Glasgow and if the model was to be applied to other cities the thresholds would need review. The impacts were grouped into people and property impacts (population, utilities, commercial properties and community services) and transport (road and rail). A separate category for transport was required as transport impacts would not be limited to the particular flooded cell and therefore could be deemed to cause significant disruption across a wider area. 
Table 1 SFFS national impact descriptions and associated grid-cell impact thresholds

\begin{tabular}{|c|c|c|c|c|}
\hline $\begin{array}{l}\text { Impact } \\
\text { category }\end{array}$ & National description & $\begin{array}{l}\text { Expected } \\
\text { National } \\
\text { Partner } \\
\text { Response }\end{array}$ & $\begin{array}{l}\text { Glasgow people } \\
\text { and property } \\
\text { threshold per grid } \\
\text { cell }\end{array}$ & $\begin{array}{l}\text { Glasgow } \\
\text { transport } \\
\text { threshold per } \\
\text { grid cell }\end{array}$ \\
\hline Minimal & $\begin{array}{l}\text { Generally no impact, however there } \\
\text { may be: } \\
\text { - Isolated and minor flooding of low- } \\
\text { lying land and roads }\end{array}$ & $\begin{array}{l}\text { Business as } \\
\text { usual }\end{array}$ & & \\
\hline Minor & $\begin{array}{l}\text { - Localised flooding of land and roads } \\
\text { - Localised flooding affecting } \\
\text { individual properties } \\
\text { - Localised disruption to key sites on } \\
\text { floodplains } \\
\text { - Local disruption to travel }\end{array}$ & $\begin{array}{l}\text { Single } \\
\text { agency } \\
\text { operational } \\
\text { response }\end{array}$ & $\begin{array}{l}1-100 \text { residential } \\
\text { properties } \\
1-2 \text { community } \\
\text { services } \\
1-2 \text { utilities } \\
1-20 \text { commercial } \\
\text { properties }\end{array}$ & \\
\hline Significant & $\begin{array}{l}\text { - Flooding affecting parts of } \\
\text { communities } \\
\text { - Damage of buildings/structures is } \\
\text { possible } \\
\text { - Possible danger to life due to fast } \\
\text { flowing/deep water/ wave } \\
\text { overtopping/ wave inundation } \\
\text { - Disruption to infrastructure } \\
\text { - Small-scale evacuation of properties } \\
\text { may be required }\end{array}$ & $\begin{array}{l}\text { Multi-agency } \\
\text { response } \\
\text { likely to be } \\
\text { needed at } \\
\text { tactical level. } \\
\text { SGoRR may } \\
\text { be } \\
\text { considered. }\end{array}$ & $\begin{array}{l}1-100 \text { residential } \\
\text { properties } \\
>2 \text { community } \\
\text { services } \\
>2 \text { utilities } \\
>20 \text { commercial } \\
\text { properties }\end{array}$ & $\begin{array}{l}>5 \mathrm{~m} \text { road } \\
>5 \mathrm{~m} \text { railway }\end{array}$ \\
\hline Severe & $\begin{array}{l}\text { - Widespread flooding affecting whole } \\
\text { communities } \\
\text { - Collapse of buildings/structures is } \\
\text { possible } \\
\text { - Danger to life due to fast flowing/ } \\
\text { deep water } \\
\text { - Widespread disruption or loss of } \\
\text { infrastructure } \\
\text { - Large scale evacuation of properties } \\
\text { may be required }\end{array}$ & $\begin{array}{l}\text { Multi-agency } \\
\text { strategic } \\
\text { response } \\
\text { likely at SCG } \\
\text { level or } \\
\text { regional level. } \\
\text { Mutual aid } \\
\text { likely with } \\
\text { perhaps } \\
\text { national co- } \\
\text { ordination. } \\
\text { SGoRR } \\
\text { convened. }\end{array}$ & $\begin{array}{l}>100 \text { residential } \\
\text { properties }\end{array}$ & \\
\hline
\end{tabular}

The process was repeated for each member of the rainfall ensemble such that the expected impacts could be combined with the probability of exceeding the threshold to allow the overall surface water flood risk to be identified within FEWS Glasgow. The complete methodological process is shown in Figure 3 and further details are provided in Moore et al. (2015). The code used in FEWS Glasgow forms part of the SFFS operational forecasting system; as such it is continually being tested and upgraded, but is not available in the public domain for external review. It was accepted that for the $10 \mathrm{~km}$ by $10 \mathrm{~km}$ domain there was limited skill in the forecast rainfall distribution and event-occurrence probabilities were expected to be low. However the topographic and land-cover data supporting G2G helped identify areas of high surface runoff whilst the receptor data enabled identification of locations with high receptor vulnerability even if uncertainty in the rainfall distribution remained high. 
The approach presented in this paper is an example of pre-simulated scenarios of flood inundation and impact combined with real-time simulation of the hydrological conditions using observed and forecast rainfall data (Henonin et al., 2013). It offers a step change in capability from the existing rainfall thresholds based approached used by the SFFS which relies on empirical knowledge of previous events.

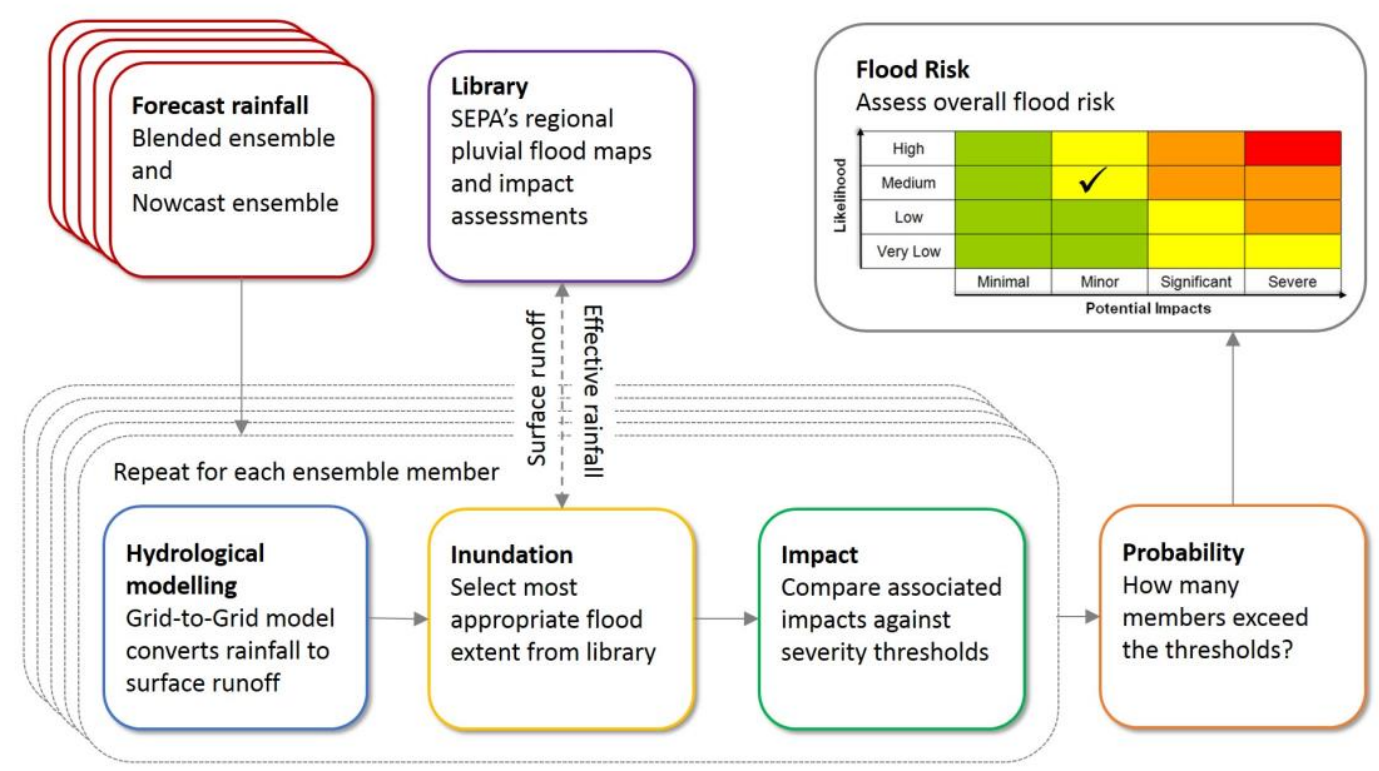

Figure 3 Surface water forecasting methodology used in FEWS Glasgow

\section{Operational implementation}

The model outputs were displayed through html web reports generated by FEWS Glasgow. The web reports showed output for selected variables of interest over the full 24 hour time period (an example is shown in Figure 6) and also broken down into six hour time-steps. These time periods were determined to best reflect the skill associated with the 24 member ensemble. The full 24 hour period could show higher probabilities than the six hour output by accounting for the probability that the threshold would be exceeded in any of the contributing six hour periods. Forecasters were able to view any forecast from the past 36 hours enabling run-to-run variability to be assessed. Gridded data were available showing the:

- probability of exceeding $20 \mathrm{~mm}$ rainfall in 3 hours

- probability of exceeding $13.5 \mathrm{~mm}$ and $16 \mathrm{~mm}$ of runoff in 3 hours

- probability of people and property impacts exceeding the minor, significant or severe threshold

- probability of transport impacts exceeding the significant threshold.

Although the surface runoff reporting thresholds were set at $13.5 \mathrm{~mm}$ and $16 \mathrm{~mm}$ in three hours for low and high runoff (based on the thresholds used by Cole et al. 2013), in some individual cells impacts were shown to start occurring when surface runoff reached $8 \mathrm{~mm}$ in three hours. The risk maps were colour-coded using the Flood Risk Matrix overall risk colours enabling flood risk to be easily identified. A $5 \%$ reporting threshold was set so that the output grids would only be populated if two or more ensemble members exceeded the threshold. This threshold was introduced to reduce the sensitivity of the model output for very low likelihood events. As well as the risk maps of gridded data, a surface runoff time-series display was produced showing the maximum surface runoff in any grid cell for each ensemble member over time (an example is shown in Figure 8). This enabled identification of the 
spread of ensembles in magnitude and time and was useful for adding additional information to the overall risk assessment.

The model was run operationally throughout the summer of 2014 and used to support the national FGS and flood alerts for the Glasgow area. For the period of the Commonwealth Games between 18 July and 4 August 2014, SEPA provided additional flood forecasting services through the SFFS directly in support of the Commonwealth Games. These services consisted of a bespoke surface water flood guidance statement for Glasgow and an increased briefing and advisory service.

The Glasgow Daily Surface Water Flood Forecast (DSWFF) was issued every afternoon at 17:00 to responders. This guidance statement contained expert interpretation of the FEWS Glasgow output including a summary of surface water flood risk (based on the Flood Risk Matrix) for the next 24 hours, a weather summary, a detailed assessment of the surface water flood risk and information on the start and end time of heightened risk. When relevant a list of possible impacts was included. In addition to the guidance statement, expert trained recipients (such as SEPA's Flood Advisors and Met Office Meteorologists and Civil Contingency Advisors) were provided with summary displays of the raw model output. These were accompanied by: a written brief explaining the key points in the forecast; comments on how the forecast should be interpreted; additional information on possible magnitude of impacts, uncertainty and timings; explanation of why there were differences to other products; some context to the forecast through comparison with previous events; and, stated when further updates would be available (an example is shown in Figure 10). The SFFS also provided a verbal brief to accompany each statement for the SEPA Resilience Officers working in the Multi Agency Control Centre during the Games.

The 17:00 issue time was selected to balance the availability of rainfall forecast and the formal briefing schedule within the Games Multi Agency Control Centre. For future use, the Steering Group identified that if the restriction was lifted on scheduled meteorological forecast run times, a product issued earlier in the afternoon ( 15:30) would be more beneficial to local councils. When required in increased risk situations an update was produced at 08:00 with the potential to produce further updates throughout the day if needed (this was not required during the Games period). In practice the written Briefing Note was updated more regularly than the formal guidance document as this was found to provide sufficient reassurance and information for briefings for the type of events experienced during the operational period.

\section{Forecasts during the Commonwealth Games}

Whilst the weather during the Commonwealth Games was largely fine, there were occasions when the additional surface water guidance provided a real benefit to the organisers and responders. This took two forms, firstly enabling the SFFS to advise that although heavy rainfall was forecast in the wider southwest Scotland region, flooding impacts in Glasgow itself were unlikely. Secondly, as was the case on the last weekend of the Games, providing information on the timing, likely impacts and possibility of flooding in Glasgow. Two examples are discussed here.

\section{Saturday 19 July 2014}

On Friday 18 July 2014 the potential for heavy and possibly thundery rain across southern Scotland was forecast for the next day (Figure 4). Based on this information a low overall flood risk, due to a very low likelihood of significant disruption from surface water flooding across a large area, was communicated through the National FGS (Figure 5). Because the 
National FGS highlighted this risk, there was a challenge to maintain consistency and clear messaging between the FGS and the Glasgow DSWFF. A regional flood alert was issued on Saturday 19 for surface water flooding.

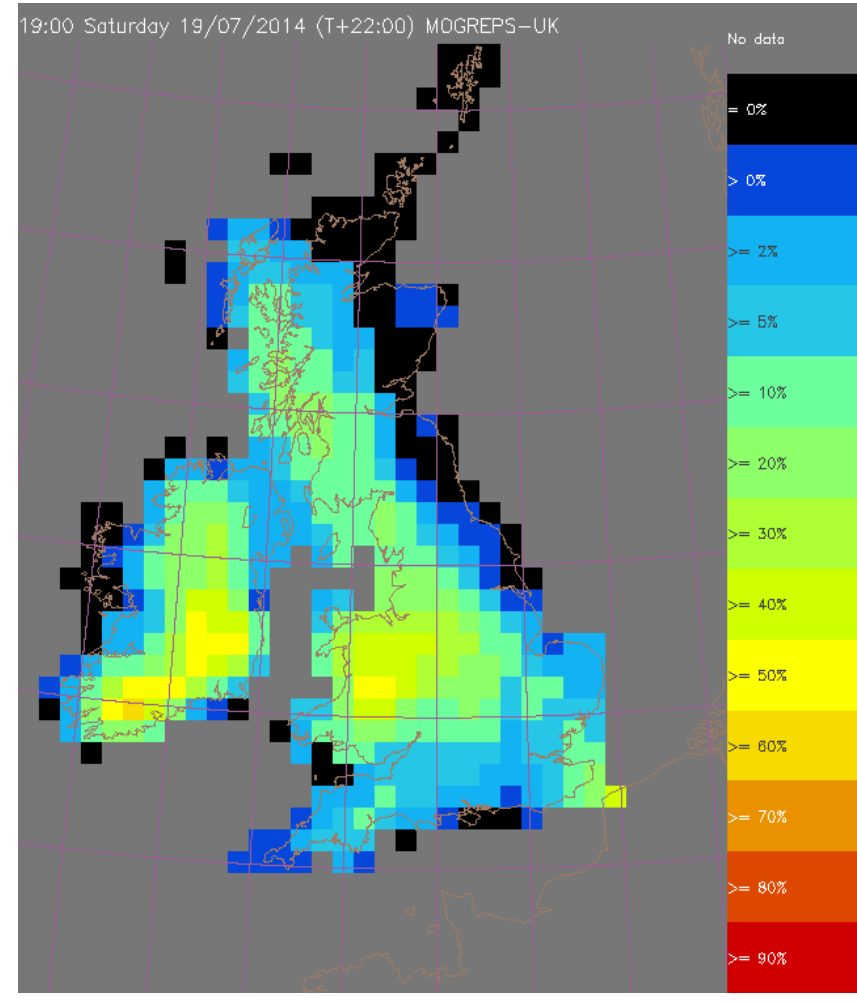

Figure 4 Heavy Rainfall Alert Tool Probability of greater than $20 \mathrm{~mm}$ rainfall in 3 hours from 21:00 18 July forecast

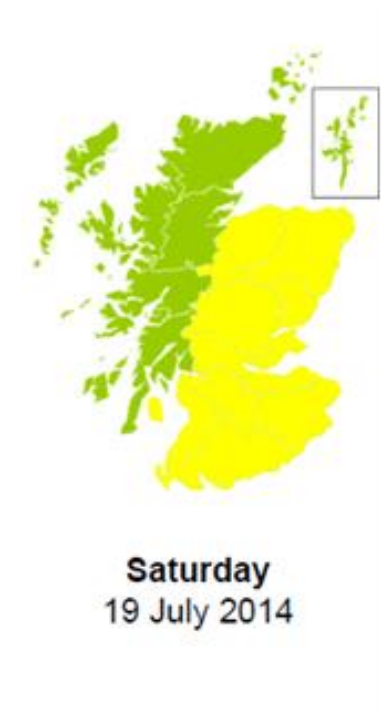

Figure 5 FGS surface water flood risk from Friday 10:30 18 July assessment

FEWS Glasgow forecast output showed that although heavy rainfall was possible there was a very low likelihood of impacts within the Glasgow area (Figure 6). There was some variability between sequential forecasts (Table 2) and this was communicated through the written and verbal briefs. The overall message to responders was that there was a very low likelihood of minor disruption in Glasgow and the increased risk identified in the FGS and flood alert was for higher ground to the south of Glasgow. FEWS Glasgow therefore enabled a more targeted message to be communicated to responders for Glasgow itself within the backdrop of the wide-area yellow warnings from the National FGS. In reality on 19 July the forecast thunderstorms did not materialise over Glasgow and no impacts were reported.

Table 2 Description of run-to-run variability in FEWS Glasgow forecasts for 18 and 19 July 2014

\begin{tabular}{|c|l|l|}
$\begin{array}{c}\text { Forecast } \\
\text { time (GMT) }\end{array}$ & Forecast type & \multicolumn{1}{c|}{ Summary of FEWS Glasgow output } \\
\hline 15:30 18 July & $\begin{array}{l}\text { Blended short- } \\
\text { range ensemble }\end{array}$ & $\begin{array}{l}\text { One ensemble member exceeding the high surface } \\
\text { runoff threshold. The other members were bunched } \\
\text { together with peak runoff of up to 7mm in 3 hours. No } \\
\text { impact threshold exceeded. }\end{array}$ \\
\hline $21: 3018$ July & $\begin{array}{l}\text { Blended short- } \\
\text { range ensemble }\end{array}$ & $\begin{array}{l}\text { This forecast identified the highest risk of any forecast } \\
\text { for the event. Six members contributed to the impact }\end{array}$ \\
\hline
\end{tabular}




\begin{tabular}{|c|c|c|}
\hline $\begin{array}{l}\text { Forecast } \\
\text { time (GMT) }\end{array}$ & Forecast type & Summary of FEWS Glasgow output \\
\hline & & $\begin{array}{l}\text { threshold exceedances with three members exceeding } \\
\text { the high runoff threshold (shown in Figure 6) }\end{array}$ \\
\hline 03:30 19 July & $\begin{array}{l}\text { Blended short- } \\
\text { range ensemble }\end{array}$ & $\begin{array}{l}\text { All surface runoff members below } 9 \mathrm{~mm} \text { in } 3 \text { hours. No } \\
\text { impact threshold exceeded. }\end{array}$ \\
\hline 09:3019 July & $\begin{array}{l}\text { Blended short } \\
\text { range ensemble }\end{array}$ & $\begin{array}{l}\text { Wide spread of ensemble members including one with } \\
\text { a much later peak. Three of which were above } 9 \mathrm{~mm} \text { in } \\
3 \text { hours. Two cells were flagged as exceeding } \\
\text { thresholds for transport and people \& property. }\end{array}$ \\
\hline $11: 3019$ July & Nowcast & $\begin{array}{l}\text { Heavy rainfall with an increased probability of } 20-39 \% \\
\text { occurrence. Transport and people \& property } \\
\text { thresholds exceeded for approximately } 25 \% \text { of cells in } \\
\text { the model domain. }\end{array}$ \\
\hline 15:30 19 July & $\begin{array}{l}\text { Blended short- } \\
\text { range ensemble }\end{array}$ & $\begin{array}{l}\text { The forecast rainfall had largely passed and no } \\
\text { thresholds were exceeded. }\end{array}$ \\
\hline
\end{tabular}




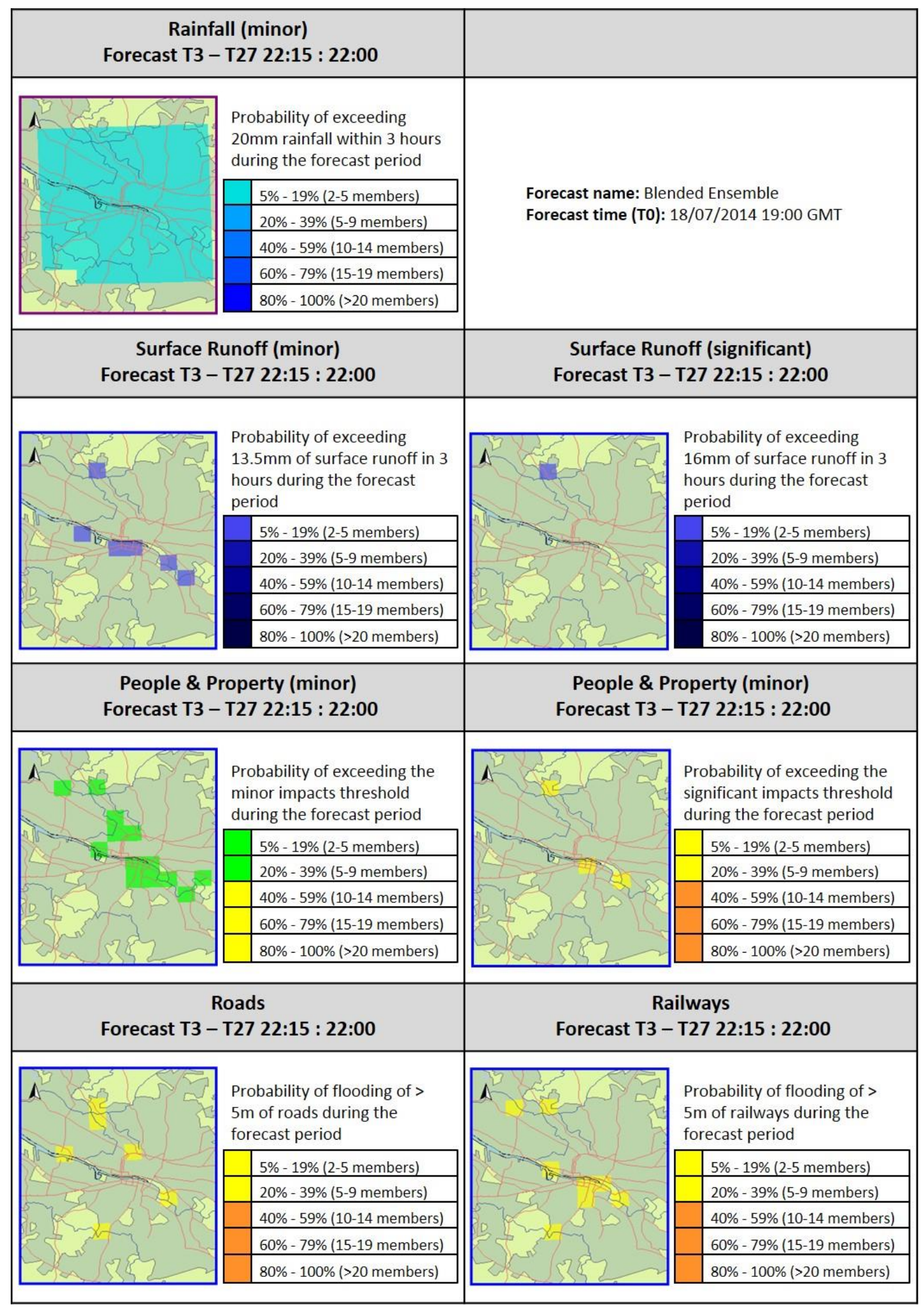

Figure 6 FEWS Glasgow 24 hour summary from 21:30 GMT 18 July MOGREPS-UK forecast run 


\section{Saturday 2 August and Sunday 3 August 2014}

On the final weekend of the Games persistent rain was forecast with possible embedded heavier downpours. There was minor disruption to athletics events on Saturday evening and Sunday's cycle road race was very wet with competitors describing the conditions as "atrocious". There were isolated reports of flooding-related disruption across the city (Table 3) and temporary diversions at Glasgow Airport due to rain and wind. The Glasgow DSWFF was raised to low overall risk for the first time on the afternoon of Sunday 3 August.

On Saturday the SFFS Heavy Rainfall Alert tool indicated that the heaviest rain was likely to fall in the northwest highlands (Figure 7a). However by Sunday morning the main area of concern was much further south (Figure 7b). There were two distinct rainfall events on Saturday evening and Sunday afternoon.

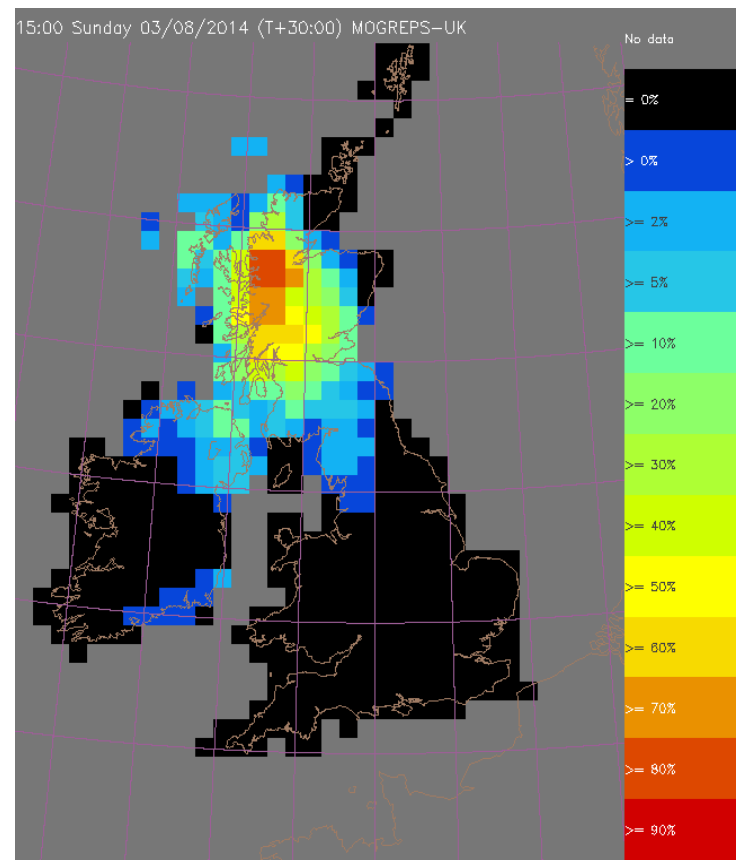

a) Forecast origin at 09:00 2 August 2014

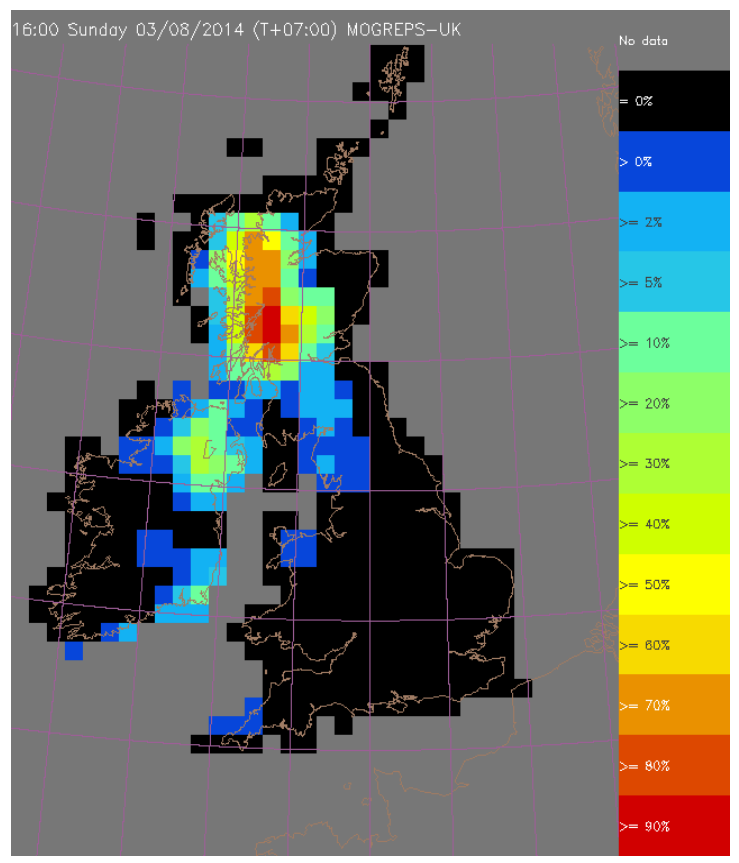

b) Forecast origin at 09:00 3 August 2014

\section{Figure 7 Heavy Rainfall Alert probability of greater than $20 \mathrm{~mm}$ in 3 hours for 3 August 2014}

The surface runoff grids for Saturday 2 August (Figure 8) showed a large spread in magnitude and timing of surface runoff. It was therefore not possible to be confident that any flooding impacts would occur and the Glasgow DSWFF stated a low likelihood of minor impacts. In contrast, the forecasts for the event on Sunday 3 August showed more consistency in timing but the probability of exceeding the impact thresholds remained low until the rainfall had started (Figure 9). At this point the Glasgow DSWFF risk level was raised to a medium likelihood of minor impacts. 


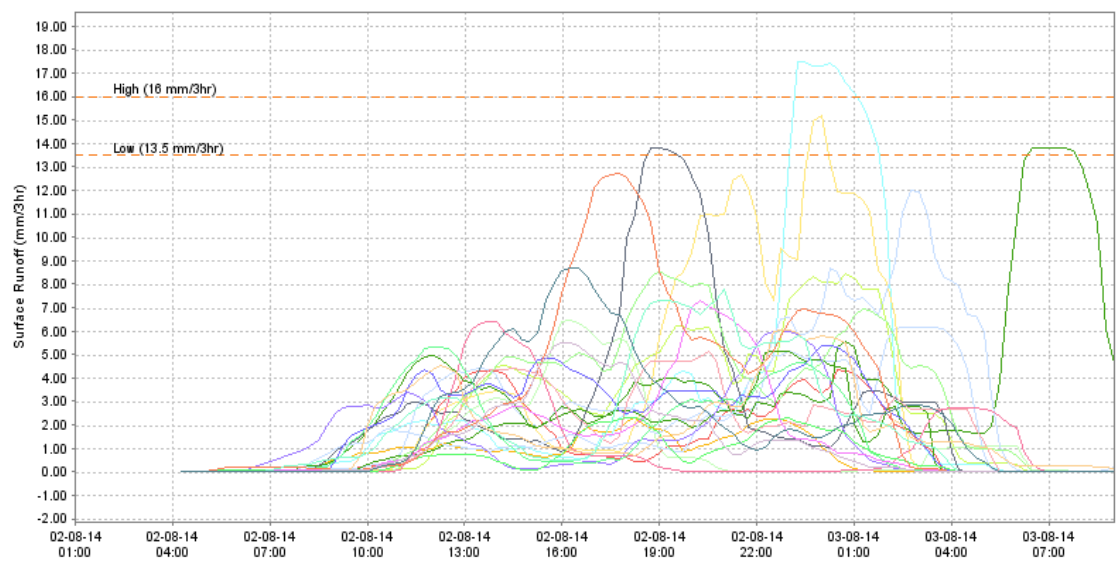

a) Forecast origin at 01002 August

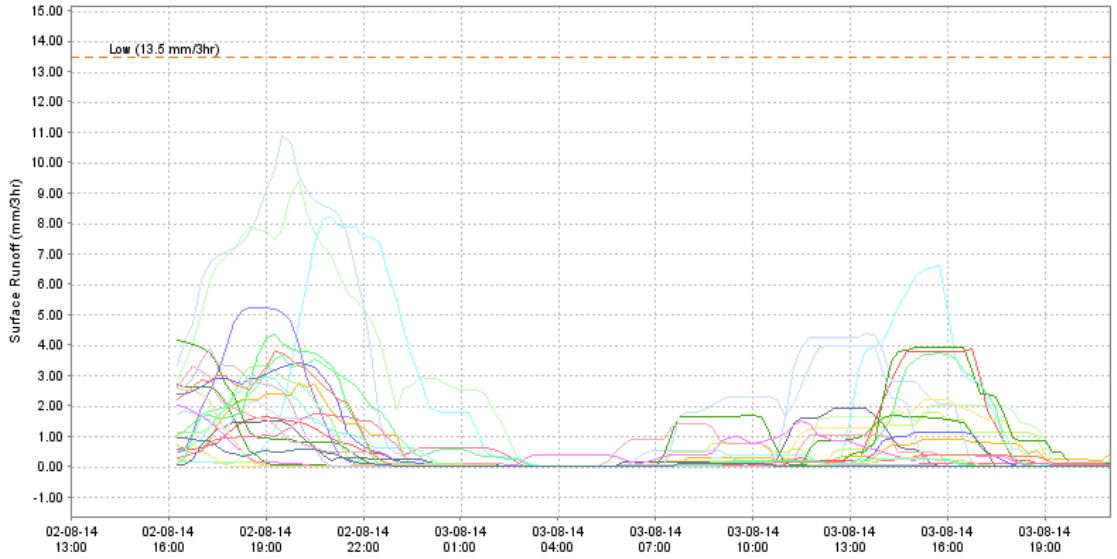

b) Forecast origin at 13002 August

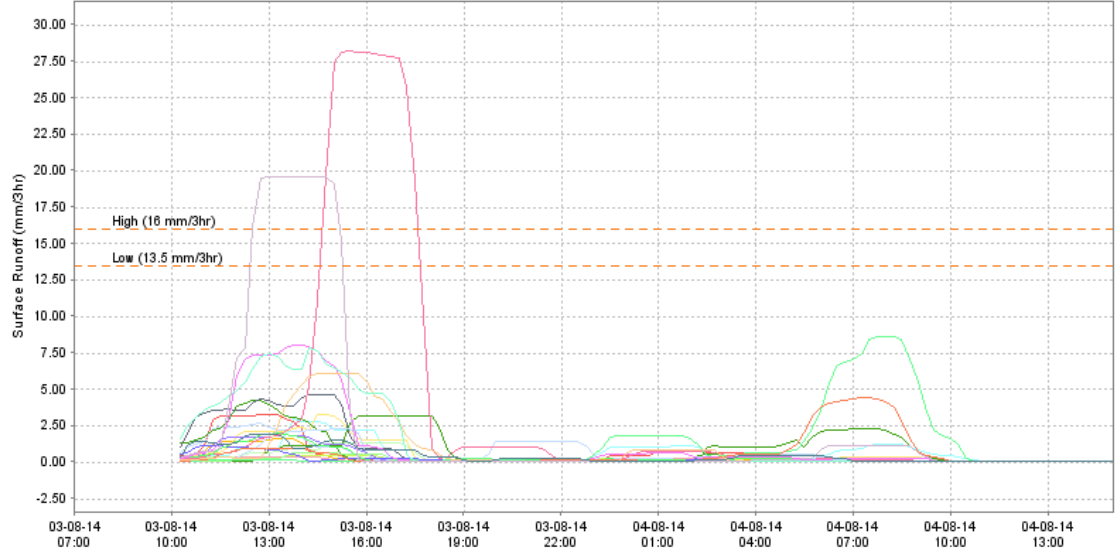

c) Forecast origin at 07003 August

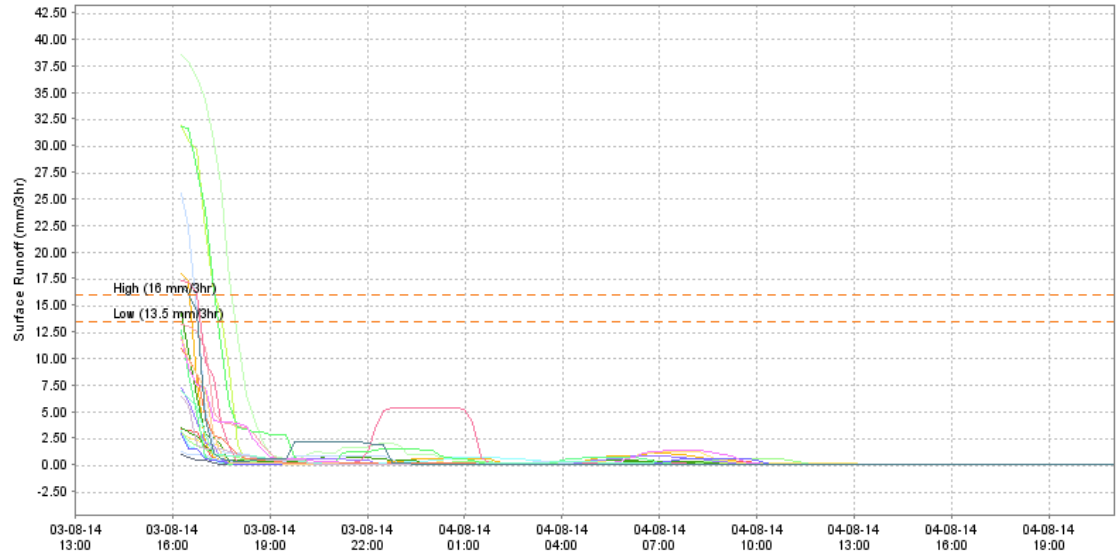

d) Forecast origin at 13003

Figure 8 FEWS Glasgow surface runoff ensemble for 2-3 August 2014 


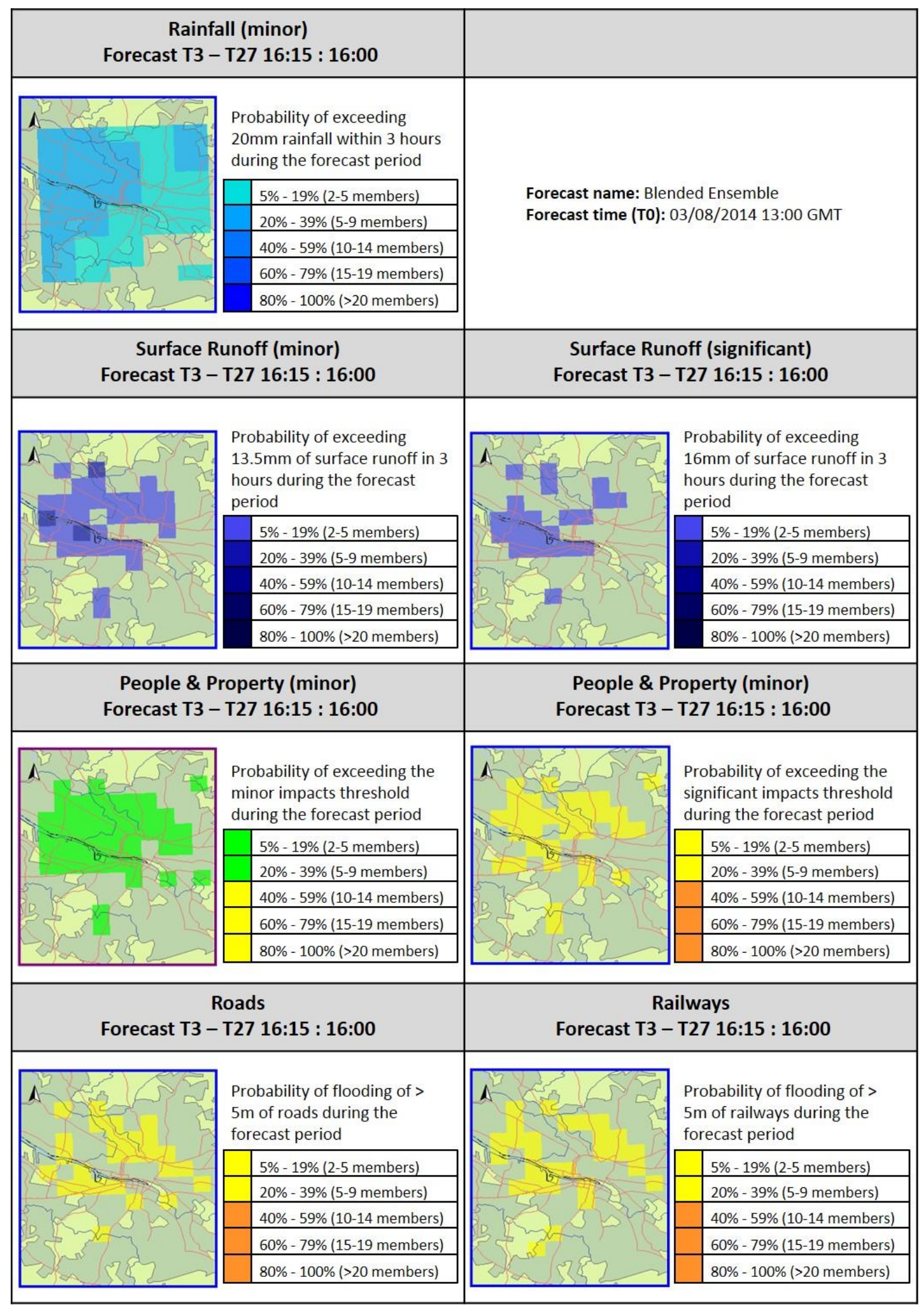

Figure 9 FEWS Glasgow 24 hour summary from 13:00 3 August MOGREPS-UK forecast
run

The messaging requirements of this event were challenging. Again there was a (yellow) warning for medium confidence of minor impacts across much of Scotland supported by the National FGS, NSWWS and flood alerts. As discussed above, it is easier to identify the 
possibility of impacts over a large area than at a city scale and as such the likelihood for Glasgow remained lower than for the national products. However due to the high profile nature of the Games it was important to communicate the potential of impacts in Glasgow to responders. The briefing channel from the SFFS via SEPA's Resilience Officers in the Multi Agency Control Centre to responders was proactively used to communicate this message. An example of one of the three minute briefs issued in support of the Glasgow DSWFF is shown in Figure 10.

This is the three minute brief from the SFFS Commonwealth Games Flood Forecasting Hydrologist on 01/08/2014 17:00

What? e.g. What is the briefing about? What is the current situation? What is known? What is the weather forecast?

1. The GDSWFF has the surface water flood risk for Glasgow for Saturday as VERY LOW.

2. A period of drier weather is expected on Friday evening then rain is forecast for Glasgow from Saturday afternoon and overnight.

3. There is the potential for periods of heavier rain within this broader wet period, particularly during the evening (typically $20-30 \mathrm{~mm}$ is possible during Saturday)

4. The national Flood Guidance Statement indicates a low flood risk for West Central Scotland however the main area of concern is over the higher ground rather than Glasgow itself

5. A SEPA flood alert has been issued for West Central Scotland again this is not directly due to concerns over Glasgow itself

6. A Met Office NSWWS warning is in place for heavy rain over a large part of the UK

Now what? e.g. What does this mean? How can the situation be interpreted? Comment on uncertainty. What should the key message to responders be?

1. At present, surface water flooding is not a major concern for Glasgow during the day on Saturday.

2. If we are unlucky enough to get one of the heavier showers, impacts should only be isolated and minor in nature, possibly causing flooding of roads in known problem spots

3. There is a high degree of uncertainty about the location and timing of the heaviest rainfall. This will be kept under review.

4. The heaviest rainfall in Glasgow is currently forecast for Saturday evening and overnight. This is outside the model range. More details will be available on Saturday morning.

5. For reference on 10 June 2014 (the event used in the FEWS Glasgow training session) the observed hourly rainfall rates were around $10-15 \mathrm{~mm}$ per hour this caused localised, short lived, minor flooding of some roads in Glasgow. The forecast for tomorrow currently doesn't suggest heavier rain than this, although it cannot be ruled out in a worst case scenario.

So what? e.g. What can this lead to? What might the implications be for Glasgow and the Games? What do we need to do? When will update be available? Will any alerts be issued?

1. Generally no disruption from flooding is expected during the day on Saturday.

2. It is advisable to keep a close eye on forecasts in case of any change for the worse.

3. A morning update of the Daily Surface Water Flood Forecasting may be issued if models start to indicate impacts for Saturday evening and overnight.

4. Given the wider risk across southern Scotland transport to and from Glasgow may be affected (refer to the national Flood Guidance Statement and Flood alerts for details)

Duty Commonwealth Games Flood Forecasting Hydrologist

Figure 10 Example three minute brief issued by email in support of the Glasgow Daily Surface Water Flood Forecast on 1 August 2014

Heavy rainfall did occur in Glasgow on both Saturday and Sunday with one SEPA raingauge at Waulkmill Glen recording a three hour maximum of $20 \mathrm{~mm}$. Collecting impact data to support surface water flood forecasting is difficult due to the transient nature of the impacts, unclear reporting channels, and lack of gauged surface runoff data. Table 3 lists impacts 
reported to the SFFS during this event and provides evidence to validate the forecast for minor impacts across Glasgow.

Table 3 Reported flooding impacts over the weekend

\begin{tabular}{|l|l|l|}
\multicolumn{1}{|c|}{ Time of report } & \multicolumn{1}{c|}{ Impact } & \multicolumn{1}{c|}{ Reported by } \\
athletics & $\begin{array}{l}\text { Large puddles and small amounts of } \\
\text { flowing water near Hampden Park } \\
\text { around 6:30pm. Some minor } \\
\text { disruption to athletics. }\end{array}$ & $\begin{array}{l}\text { Member of SEPA attending } \\
\text { the Games }\end{array}$ \\
\hline 21:17 2 August & $\begin{array}{l}\text { Giffnock flooding from drains/sewer } \\
\text { and burn next to road. Not affecting } \\
\text { property. }\end{array}$ & $\begin{array}{l}\text { Member of the public to } \\
\text { SEPA SCC }\end{array}$ \\
\hline 21:412 August & $\begin{array}{l}\text { Helensburgh drain overflow flooding } \\
\text { shop }\end{array}$ & $\begin{array}{l}\text { Member of the public to } \\
\text { SEPA SCC }\end{array}$ \\
\hline 14:39 3 August & $\begin{array}{l}\text { Paisley flooding from small burn. } \\
\text { Occurred last night and again today. }\end{array}$ & $\begin{array}{l}\text { Member of the public to } \\
\text { SEPA SCC }\end{array}$ \\
\hline 15:13 3 August & Flooding on the M8 Junction 15 & $\begin{array}{l}\text { SEPA Resilience Officer in } \\
\text { the MACC }\end{array}$ \\
\hline 15:13 3 August & $\begin{array}{l}\text { Drains lifting on the A82 cut off from } \\
\text { the M8 }\end{array}$ & $\begin{array}{l}\text { SEPA Resilience Officer in } \\
\text { the MACC }\end{array}$ \\
\hline 16:59 3 August & $\begin{array}{l}\text { Large amount of surface water at the } \\
\text { Baldinnie Road Park \& Ride }\end{array}$ & $\begin{array}{l}\text { SEPA Resilience Officer in } \\
\text { the MACC }\end{array}$ \\
\hline
\end{tabular}

MACC: Multi Agency Control Centre (for the Commonwealth Games) SCC: SEPA Communication Centre

\section{Discussion}

This paper has demonstrated a new risk-based forecasting model for surface water flooding. It improves upon the existing rainfall thresholds approach in Glasgow by providing surface water flood guidance at a city scale with a 24 hour lead-time using emerging meteorological forecast products and hydrological tools. It is acknowledged that a further step-change could be possible with real-time $2 \mathrm{D}$ inundation modelling. However, to help meet the priority requirements of end-users for risk-based forecasts, as identified by the Glasgow Steering Group, any such model would need to be run using the full MOGREPS-UK rainfall ensemble. To justify the investment in computational capabilities, further evidence is required to demonstrate if the real-time inundation modelling approach would deliver any additional benefits beyond the static library approach presented in this paper; especially given the current uncertainty in convective rainfall forecasts at a sub city scale and understanding of impacts.

The use of FEWS Glasgow during the Commonwealth Games highlighted that on occasions there is significant run-to-run variability in the forecasts for surface water events. This is in part to be expected given the relatively small 24 member MOGREPS-UK ensemble used as meteorological input. Operationally it was possible to mitigate for this by looking at consecutive model runs when assessing the surface water flood risk, effectively generating a larger time-lagged ensemble. In the long term, further increases in the ensemble size should help decrease the run-to-run sensitivity. 
While technical capabilities are continually advancing, it is clear that any method of forecasting surface water flooding for city-scale warnings at lead-times of greater than a couple of hours will be probabilistic. Alongside the technical developments there is a need to consider how to effectively communicate probabilistic flood forecasts to end-users, especially for low confidence events. Surface water flood forecasting is an example of a new generation of forecasting where it is accepted that the meteorologist cannot add value by modifying the rainfall forecast products themselves, but by interpreting the output and providing briefing material can offer a value-added service (Stuart et al., 2006; Pagano et al., 2014). The communication tools to support surface water flood forecasting need to take account of this. During the Commonwealth Games the briefing requirements around the Glasgow DSWFF were high. This was partly due to it being a new product and a high profile event, but communication will remain a long-term challenge due to the uncertainty in forecasting surface water events and will need to be considered in the operational design of surface water forecasting systems.

The two events presented in this paper, along with experience of other low risk events in Glasgow during the summer of 2014, demonstrate that the tool is suitable for operational use and could be extended to other cities where there is a library of static flood impact assessments and an available hydrological model to convert forecast rainfall to surface water runoff. The operational pilot during summer 2014 only included forecasts for minor impact events. Further testing is required to confirm the suitability of the model for more severe events as the output is sensitive to the impact thresholds used. The focus of this study was to test an end-to-end operational model rather than to address the challenging question of how to validate probabilistic impact-based forecasts. Further quantitative validation of the model over a longer time period, or with case study data from historical events, would clearly be beneficial.

In addition to forecasting applications, a detailed review of the model output compared to observations over longer durations (annual plus time scales) could be used to inform strategic decision making. For example if the model is consistently performing poorly in certain areas this could indicate a valuable location to install new monitoring equipment or to review the underlying flood risk mapping. Alternatively, areas which are shown not to suffer surface water flooding despite heavy rainfall could be identified as sensible locations to allow future development.

\section{Conclusions}

This paper has demonstrated an operational end-to-end risk-based process for surface water flood forecasting utilising emerging science and incorporating this within an existing operational framework. The operational pilot during the Commonwealth Games illustrated the high resourcing requirements needed to support surface water flood forecasting. Traditionally these resources have been assumed to be computational, and this is still the case with the run-to-run forecast variability evident in this study illustrating the need for larger ensembles. Further, the decision not to include real-time inundation modelling or explicit representation of the sewer network highlights the requirement for continued development aligned to advances in computing, including GPUs and Cloud services. It is also well acknowledged that surface water flood risk modelling requires a better understanding of impacts in urban areas. However this paper has argued that the challenge of the human resourcing requirement to support the communication of probabilistic forecasts has been underestimated. It demands further development of innovative solutions to support the increased uncertainty in surface water 
flood forecasting compared to the established methods used for traditional fluvial and coastal flood events.

As articulated by René et al. (2014, p575) "the issue we need to address in flood forecasting is recognising and accepting that it is always uncertain, but provides valuable information to end users." Despite the uncertainty and challenging communication requirements, the feedback from the Commonwealth Games Multi Agency Control Centre was positive with end-users valuing the surface water guidance in support of their decision-making when heavy rainfall was forecast. The experience gained from developing and using the Glasgow surface water flood forecasting tool will help inform the continued development of surface water flood forecasting capabilities in Scotland.

\section{Acknowledgements}

This work was part funded through the Centre of Expertise for Waters (CREW) in Scotland. Bob Moore and Steve Cole have been working with the Flood Forecasting Centre (for England \& Wales) as part of the Natural Hazards Partnership (NHP) to develop a national surface water flood forecasting tool. The work presented in this paper built on some of the concepts developed within the NHP but applied them at a smaller scale and integrated them with existing SFFS tools.

The authors would like to acknowledge the hard work of the SFFS flood forecasting hydrologists and meteorologists who provided operational surface water flood guidance during the Commonwealth Games. We are also grateful for the contributions of the project Steering Group in helping establish the end-user requirements.

\section{References}

Bell, V.A., Kay, A.L., Jones, R.G., Moore, R.J. and Reynard, N.S. (2009) Use of soil data in a grid-based hydrological model to estimate spatial variation in changing flood risk across the UK. J. Hydrol., 377, 335-350.

Bowler, N.E.H., Pierce, C.E. and Seed, A.W. (2004) Development of a precipitation nowcasting algorithm based upon optical flow techniques. J. Hydrol., 288, 74-91.

Bowler, N.E.H., Pierce, C.E. and Seed, A.W. (2006) STEPS: a probabilistic precipitation forecasting scheme which merges an extrapolation nowcast with downscaled NWP. Quart. J. Roy. Meteor. Soc., 132, 2127-2155.

Cabinet Office (2008) The Pitt Review: lessons learned from the 2007 floods. Cabinet Office, London.

CH2MHILL (2014) Introducing ISIS FAST [online] Flood Modeller Suite. https://www.floodmodeller.com/en-gb/products/desktop/r/legacy-software/3/isis-fast/ [accessed December 2014]

Chen, J., Hill, A.A. and Urbano, L.D. (2009) A GIS-based model for urban flood inundation. J. Hydrol., 373, 184-192.

Chen A.S., Evans, B., Djordjevic, S. and Savic, D.A. (2012) Multi-layered coarse grid modelling in 2D urban flood simulations. J. Hydrol., 470-471, 1-11.

CIWEM (2009) Integrated urban drainage modelling guide available [online] http://www.ciwem.org/media/44495/WaPUG IUD Modelling Guide Draft Rev1 v28 (June 09) v01-001.pdf [acessed November 2014] 
Clark, A.J., Gallus, W.A., Jr., Xue, M. and Kong, F. (2009) A comparison of precipitation forecast skill between small convection-permitting and large convectionparameterizing ensembles. Wea. Forecasting, 24, 1121-1140.

Clark, A.J., Kain, J.S., Stensrud, D. J., Xue, M., Kong, F., Coniglio, M. C., Thomas, K. W., Wang, Y., Brewster, K., Gao, J., Wang, X., Weiss S. J. and Du, J. (2010) Probabilistic precipitation forecast skill as a function of ensemble size and spatial scale in a convection-allowing ensemble. Mon. Wea. Rev., 139, 1410-1418.

Cole, S., Moore, R., Aldridge, T., Lane, A. and Laeger, S. (2013) Real-time hazard impact modelling of surface water flooding: some UK developments. In: Butler, D., Chen, A.S., Djordjević, S. and Hammond, M. (eds.), Proc. Int. Conf. on Flood Resilience: Experiences in Asia and Europe (ICFR 2013), University of Exeter, 6pp.

Cole, S.J., Moore, R.J. and Mattingley, P.S. (2015) Surface Water Flooding Component for NHP HIM: Phase 1 Report. Contract Report to the Environment Agency, Research Contractor: Centre for Ecology \& Hydrology, Environment Agency, Bristol, UK, 55pp.

Cranston, M., Maxey, R., Tavendale, A., Buchanan, P., Motion, A., Cole, S., Robson, A., Moore, R.J. and Minett, A. (2012) Countrywide flood forecasting in Scotland: challenges for hydrometeorological model uncertainty and prediction. In Moore, R.J., Cole, S.J. and Illingworth, A.J. (ed.) Weather Radar and Hydrology, IAHS Publ. 351, 538-543.

Dale, M., Davies, P. and Harrison, T. (2012) Review of recent advances in UK operational hydrometeorology. Proc. ICE Water Management, 166, 55-64.

Directive 2007/60/EC of the European Parliament and of the Council of 23 October 2007 on the assessment and management of flood risks.

Done, J., Davis C.A. and Weisman M.L. (2004) The next generation of NWP: explicit forecasts of convection using the Weather Research and Forecasting (WRF) Model. Atmos. Sci. Let., 5, 110-117.

Fernández, D.S. and Lutz, M.A. (2010) Urban flood hazard zoning in Tucumán Province, Argentina, using GIS and multicriteria decision analysis. Engineering Geology, 111, 90-98.

Flood Risk Management (Scotland) Act 2009 (asp 6).

Germann, U. and Zawadzki, I. (2002) Scale-dependence of the predictability of precipitation from continental radar Images. Part I: description of the methodology. Mon. Wea. Rev., 130, 2859-2860.

Germann, U. and Zawadzki, I. (2004) Scale dependence of the predictability of precipitation from continental radar images. Part II: probability forecasts. J. Appl. Meteorol., 43, 74-89.

Ghimire, S., Dunn, S., Golding, B.W., Pierce, C.P., Roberts, N.M., Moore, R.J., Cole, S.J. and Speight, L. (2013a) Surface water flood forecasting for urban communities: a review. CREW Project CRW2012/3, The James Hutton Institute, Aberdeen, UK, 5pp.

Ghimire, S., Moore, R.J. and Cole, S.J. (2013b) Review of surface water flood modelling and forecasting for urban communities. CREW Project CRW2012/3, Contract Report by The James Hutton Institute and Centre for Ecology \& Hydrology, The James Hutton Institute, Aberdeen, UK. Available online at www.crew.ac.uk/publications

Glenis, V., McGough, A., Kutija, V., Kilsby, C. and Woodman, S. (2013) Flood modelling for cities using cloud computing. J. Cloud Computing: Advances Systems and Applications, 2(7), 1-14.

Golding, B.W. (1998) Nimrod: a system for generating automated very short range forecasts. Meteorol. Appl., 5(1), 1-16.

Golding, B.W. (2009) Long lead time flood warnings: reality or fantasy? Meteorol. Appl., 16(1), 3-12. 
Golding, B.W., Ballard, S.P., Mylne, K., Roberts, N., Saulter, A., Wilson, C., Agnew, P., Davis, L.S., Trice, J., Jones, C., Simonin, D., Li, Z., Pierce, C., Bennett, A., Weeks, M. and Moseley. S. (2014) Forecasting capabilities for the London 2012 Olympics. Bull. Amer. Meteor. Soc., 95, 883-896.

Halcrow (2011) Developing alerting criteria for surface water flooding. Report NA096 for the Environment Agency, Bristol, UK, 25pp + appendices.

Halcrow (2012) Rainfall guidance and flooding impacts: technical report. Halcrow Group Limited, Edinburgh.

Henonin, J., Russo, B., Mark, O. and Gourbesville, P. (2013) Real-time urban flood forecasting and modelling - a start of the art. J. Hydroinformatics, 15(3), 717-736.

Ipsos MORI (2013) 2013 Emergency Responder Survey. Report to SEPA, 51pp.

JBA Consulting (2014a) Assessing the flood risk management benefits of property level protection: technical and economic appraisal report. Report to Scottish Government, 53pp.

JBA Consulting (2014b) Derivation of a regional pluvial flood hazard dataset, Scotland methodology report. Report to SEPA.

Lamb, R., Crossley, M. and Waller, S. (2009) A fast two-dimensional floodplain inundation model. Proc. ICE Water Management, 162(6), 262-270.

Leoncini, G., Roberts, N. Lean H. and Golding B. (2012) $8^{\text {th }}$ July 2011 floods in Scotland. Met Office report to SEPA.

Leoncini, G., Plant, R.S., Gray S.L. and Clark P.A. (2013) Ensemble forecasts of a floodproducing storm: comparison of the influence of model-state perturbations and parameter modifications. Q. J. R. Meteorol. Soc., 139, 198-211.

Maxey, R., Cranston, M., Tavendale, A. and Buchanan, P. (2012) The use of deterministic and probabilistic forecasting in countrywide flood guidance in Scotland. Hydrology for a changing world, BHS eleventh National Hydrology Symposium, Dundee, UK.

De Moel, H., Van Alphen, J. and Aerts, J. (2009) Flood maps in Europe - methods availability and use. Nat. Hazards Earth Syst. Sci., 9, 289-301.

Moore, R.J., Cole, S.J., Bell, V.A. and Jones, D.A. (2006) Issues in flood forecasting: ungauged basins, extreme floods and uncertainty. In: Tchiguirinskaia, I., Thein, K.N.N. and Hubert, P. (ed) Frontiers in Flood Research, 8th Kovacs Colloq., UNESCO, Paris, 2006, IAHS Publ. 305, 103-122.

Moore, R.J., Bell, V.A., Cole, S.J. and Jones, D.A. (2007) Rainfall-runoff and other modelling for ungauged/low-benefit locations. Science Report - SC030227/SR1, Research Contractor: CEH Wallingford, Environment Agency, Bristol, UK, 249pp.

Moore, R.J., Cole, S.J., Dunn, S., Ghimire, S., Golding, B.W., Pierce, C.E., Roberts, N.M. and Speight, L. (2015) Surface water flood forecasting for urban communities, CREW report CRW2012_03, 32pp. Available online at www.crew.ac.uk/publications

Moore, R.J. and Jones, D.A. (1997) Linking hydrological and hydrodynamic forecast models and their data. In: R.Casale, K. Havno and P. Samuels (ed) Ribamod: River basin modelling, management and flood mitigation. Concerted action. Proc. First Expert Meeting, Copenhagen, 10-11 October 1996, EUR 17456 EN, European Commission, 37-56.

MWH (2002) Glasgow East End flooding of $30^{\text {th }}$ July 2002. Report to Scottish Water (South West Area), MWH UK Ltd, 13pp.

Neal, J., Fewtrell, T., Bates, P. and Wright. N. (2010). A comparison of three parallelisation methods for 2D flood inundation models. Environ. Modelling and Software, 25(4): 398-411.

NHP (2013) Home page [online] Natural Hazards Partnership www.metoffice.gov.uk/nhp [accessed January 2015] 
Ochoa-Rodriguez, S., Thraves, L. and Johnston, A. (2013) Surface water flood warnings in England: an overview, assessment and recommendations based on survey responses and workshops. In: Butler, D., Chen, A.S., Djordjević, S. and Hammond, M. (eds) Proc. Int. Conf. on Flood Resilience: Experiences in Asia and Europe (ICFR 2013), University of Exeter.

Pagano, T.C., Wood, A.W., Ramos, M-H., Cloke, H.L., Pappenberger, F., Clark, M.P., Cranston, M., Kavetski, D., Mathevet, T., Sorooshian, S. and Verkade. J.S .(2014) Challenges of operational river forecasting. Journal of Hydrometeorology, 15(4), 1692-1707.

Price, D., Hudson, K., Boyce, G., Schellekens, J., Moore, R.J., Clark, P., Harrison, T., Connolly, E. and Pilling, C. (2012) Operational use of a grid-based model for flood forecasting. Water Management, 165(2), 65-77.

René, J-R., Djordjević, S., Butler, D., Madsen, H. and Mark, O. (2014) Assessing the potential for real-time urban flood forecasting based on a worldwide survey of data availability. Urban Water Journal, 11(7), 573-583.

Schellart, A., Ochaoa, S., Simoes, N., Wang, L-P., Rico-Ramirez, M., Liguori, S., Duncan, A., Chen, A., Keedwell, E., Djordjevic, S., Savic, D., Saul, A. and Makismovic, C. (2011) Urban pluvial flood modelling with real time rainfall information - UK case studies. $12^{\text {th }}$ Int. Conf. on Urban Drainage, 11-16 September, Porto Alegre, Brazil.

Schubert, J.E. and Sanders, B.F. (2012). Building treatments for urban flood inundation models and implications for predictive skill and modelling efficiency. Adv. Water Resour., 41, 49-64.

Schumann, G.J.P., Neal, J.C., Mason, D.C., and Bates, P.D. (2011) The accuracy of sequential aerial photography and SAR data for observing urban flood dynamics, a case study of the UK summer 2007 floods. Remote Sensing of Environment, 115, 2536-2546.

SEPA (2011) The National Flood Risk Assessment [online]. Scottish Environment Protection Agency, http://www.sepa.org.uk/flooding/flood risk management/national flood risk assess ment.aspx [accessed November 2014]

SEPA (2013) Flood Maps [online] Scottish Environment protection Agency. http://map.sepa.org.uk/floodmap/map.htm [accessed December 2014]

SFFS (2015) Your guide to using the flood guidance statement, third publication, Scottish Environment Protection Agency and Met Office, http://www.sepa.org.uk/media/149570/sffs fgs user guide 2015.pdf [accessed 1 June 2015]

Simoes, N., Ochoa, S., Leitao, J.P., Pina, R., Sá Marques, A. and Maksimovie, C. (2011) Urban drainage models for flood forecasting: 1D/1D, 1D/2D and hybrid models. 12th Int. Conf. on Urban Drainage, 11-16 September, Porto Alegre, Brazil.

Smith, L.S., Liang, Q., James, P. and Lin, W. (2015) Assessing the utility of social media as a data source for flood risk management using a real-time modelling framework, Journal of Flood Risk Management, Early view, 1-11

Stuart, N., Market, P.S., Telfeyan, B., Lackmann, G.M., Carey, K., Brooks, H.E., Nietfeld, D., Motta, B.C., Reeves, K. (2006) The Future of Humans in an Increasingly Automated Forecast Process. Bull. Amer. Meteor. Soc., 87, 1497-1502.

Tang, Y., Lean, H. W. and Bornemann, J. (2013) The benefits of the Met Office variable resolution NWP model for forecasting convection. Meteorol. Apps., 20, 417-426.

Tingsanchali, T. (2012) Urban flood disaster management. Procedia Engineering, 32, 25-37.

van Herk, S., Zevenbergen, C., Ashley, R. and Rijke, J. (2011) Learning and Action Alliances for the integration of flood risk management into urban planning: a new framework from empirical evidence from The Netherlands. Environmental Science \& Policy, 14 (5), 543-554. 
Werner, M., Schellekens, J., Gijsbers, P., van Dijk, M., van den Akker, O. and Heynert, K. (2013) The Delft-FEWS flow forecasting system. Environmental Modelling \& Software, 40, 65-77. 